\author{
С.В. Гадецька ${ }^{1}$, В.Ю. Дубницький ${ }^{2}$ Ю.І. Кушнерук ${ }^{3}$, Л.Д. Філатова ${ }^{2}$, О.І. Ходирєв ${ }^{2}$ \\ ${ }^{1}$ Харківський національний автомобільно-дорожній університет, Харків \\ ${ }^{2}$ Навчально-науковій інститут "Каразінський банківський інститут" \\ Харківського національного університету ім. В.Н. Каразіна, Харків \\ ${ }^{3}$ Харківський національний університет Повітряних Сил ім. І. Кожедуба, Харків
}

\title{
ГЕОМЕТРИЧНІ ХАРАКТЕРИСТИКИ S-ПОДІБНИХ (ЛОГІСТИЧНИХ) КРИВИХ, ЩО ЗАСТОСОВУЮТЬСЯ ПРИ МОДЕЛЮВАННІ ЯВИЩА ГІСТЕРЕЗИСУ
}

В роботі розглянуто методи побудови математичних моделей явища гістерезису, які придатні для його опису в об'єктах довільної природи. В результаті аналізу літератури встановлено, щзо явище гістерезису спостерігається не тільки у фізичі, але і в багатьох галузях знань, таких як моделювання антитерористичних операчій, опис роботи різних механізмів, гідрогеологія, економіка, планування навчального прочесу. Показано, щуо в цих випадках найбільи вдалим методом апроксимації петлі гістерезису буде використання S-образних (логістичних) кривих. Наведено приклад побудови S-подібної (логістичної) кривої з використанням перетворення графіка функиї гіперболічного тангенсу. В роботі досліджено властивості двохпараметричних, трьохпараметричних та чотирьохпараметричних логістичних кривих, S-подібних кривих Гомперйа і Вейбулла. В роботі наведено вирази для визначення таких властивостей кривих, як: дотична в точці $M\left(x_{0}, y_{0}\right)$, кривина кривої в довільній точиі $M(x, y)$, радіус кривини в довільній точиі $M(x, y)$, координати $\xi, \eta$ цеентру С кривини, еластичність функиії по аргументу і взаємна еластичність по параметрах. Останнє особливо важливе при дослідженні прочесів, пов'язаних з отриманням матеріалів із заданими властивостями. Співвідношення еластичності надають можливість вивчити вплив відносної зміни властивостей зовнішнього середовища на відносну зміну значення функиї, яку вивчають. Гранична норма заміщення надає можливість оцінити вплив внутрішніх властивостей по відношенню до явища, щзо вивчається, на значення функиії, щуо вивчається. Це може бути корисним при синтезі матеріалів із заданими властивостями.

Ключові слова: гістерезис, модель гістерезису, S-подібні (логістичні) криві, двохпараметричні, трьохпараметричні чотирьохпараметричні логістичні криві, криві Гомперияа і Вейбулла.

\section{Вступ}

Постановка проблеми. При вивченні деяких фізичних процесів можна спостерігати явище, при якому фізична величина, що характеризує стан об'єкту, неоднозначно залежить від фізичної величини, що характеризує зовнішні умови. Інакше кажучи, за одних і тих же зовнішніх умов стан об'єкту дослідження може бути різним, залежним від його стану в попередні моменти часу. Це явище німецький фізик Е. Варбург (1846-1931) в 1880 р. назвав гістерезисом [1]. За іншими відомостями [14] першість належить англійському фізикові Д.А. Івінгу (18551935), що виявив це явище в 1890 р. Із зіставлення цих дат можна припустити, що ці дослідники цілком могли знати про роботи один одного.

Явище гістерезису обумовлене тим, що для зміни стану предмету дослідження при зміні зовнішніх умов завжди потрібний певний час; іншими словами, реакція тіла відстає від причин, що їх викликали, але чим повільніше змінюються зовнішні умови, тим менше це відставання. Графік такої залежності, показаний на рис. 1, отримав назву петлі гістерезису.

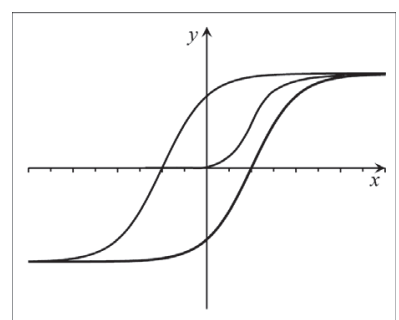

Рис. 1. Графік типової петлі гістерезису

Явище гістерезису можна спостерігати не тільки у фізиці, але і в багатьох галузях знань. Наприклад, в роботі [2] поняття гістерезису використано для моделювання антитерористичних операцій. У роботі [3] поняття гістерезису використано при моделюванні деформації механізмів, призначених для стикування космічних апаратів, в роботі [4] поняття гістерезису було використано при описанні водоутримуючої здатності грунтів. Виникнення в економіці явищ, які можуть бути задовільно описані з використанням поняття гістерезису, розглянуті в роботі [5]. Детально суть явища гістерезису стосовно феромагнітних матеріалів описана в роботі [6]. Фізичні процеси, що протікають в матеріалі і викликають явище гістерезису, детально розглянуті в робо- 
тах [7-11]. Виникнення гістерезису в системах, які можуть бути описані нелінійними диференціальними рівняннями, незалежно від фізичної природи досліджуваного явища, розглянуто в роботах [1213]. Аналогія між явищем магнітного гістерезису i макроекономічними процесами вивчена в роботі [14]. Далі будуть розглянуті роботи, в яких приведено математичні моделі гістерезису, придатні для опису цього явища в об'єктах довільної природи, але виклад виконаний $з$ використанням термінів, вживаних при вивченні електромагнітних явищ. Ця ситуація аналогічна ситуації, що має місце в рівняннях математичної фізики, в якій одне 3 ключових рівнянь носить назву телеграфного [15], але має, зрозуміло, значно велику область застосування, ніж та, яка виходить 3 його назви.

Піонерською роботою в області побудови математичних моделей гістерезису, на нашу думку, слід вважати виконану в 1924 р. роботу [16]. У цій роботі показано, що петлі гістерезису можуть бути отримані в результаті рішень інтегральних рівнянь типу Вольтерра. Геометричний образ цих рішень співпадає з графіками, подібними до петель гістерезису різного вигляду. Згодом ця робота не згадувалася дослідниками з причини, швидше за все, пов'язаної з непростою долею автора роботи [16]. Результати цієї роботи отримали своє продовження в роботі [17]. Автори цієї роботи використовували, виходячи 3 механічних аналогій, диференціальні рівняння, кусково-лінійна апроксимація розв'язань яких надала можливість описати петлю гістерезису. У цій же роботі сформульовані вимоги, яким повинні задовольняти математичні моделі гістерезису. Вони повинні давати можливість отримувати петлі гістерезису різного вигляду, бути досить простими, щоб отримувані результати були доступні для огляду і не приводили до “нечитабельних" виразів. У такому разі результати моделювання бажано отримувати у вигляді квадратур або, навіть, у вигляді простих аналітичних співвідношень. Моделі повинні давати можливість отримувати змістовні висновки шляхом аналізу впливу компонентів моделі на результат моделювання. На думку автора роботи [18] найбільш поширені методи апроксимації петлі гістерезису в цілому і ії елементів наступні:

1. Заміна петлі гістерезису рівновеликим еліпсом.

2. Апроксимація різних ділянок петлі гістерезису лініями, кожна з яких має різні рівняння (окремо для зростаючої і спадної частини).

3. Подання петлі гістерезису у вигляді розв’язку інтегрального рівняння типу рівняння Вольтерра.

4. Кусково-лінійна апроксимація фрагментів кривих гістерезису, які мають змістовне значення.

5. Опис петлі гістерезису в прямокутній систе- мі координат у вигляді суми двох кривих, які в роботі названо основною і допоміжною.

6. Можливість опису петлі гістерезису в полярних координатах.

У роботі [19] запропонована класифікація найбільш поширених типів петель гістерезису, що найчастіше зустрічаються на практиці. Для опису отриманих моделей в цій роботі досліджено спосіб опису петлі гістерезису у вигляді їі кусочно-лінійної апроксимації, версія якої запропонована в роботі [20]. Розглянуто представлення петлі гістерезису в класі інтегральних операторів, тобто виконано повернення на новій основі до ідей роботи [16]. Важлива відмінність роботи [19] від раніше виконаних в тому, що в ній запропонована класифікація геометричних типів петель гістерезису і запропоновані рівняння для зміни координат петель в безрозмірній формі. Таким чином, запропоновані в цій роботі методи мають ширшу область застосування, ніж методи, що враховують, навіть у першому наближенні, фізичні особливості процесу. Особливо, на нашу думку, слід виділити роботу [21]. Автор цієї роботи показав, що рівняння петлі гістерезису можна представити як суму рівнянь верхньої і нижньої гілок гістерезису і їх добуток. Показано, при яких обмеженнях на отримані рівняння можна отримати петлю гістерезису, симетричну відносно початку координат. У список літератури включені роботи [22-23]. Причини цього слід обумовити окремо. Авторам даної роботи не вдалося ознайомитися із змістом цих робіт 3 причин, пов'язаних із здійсненням протиепідемічних заходів. Рішення про включення в огляд робіт [22-23] автори прийняли тому, що на них, за даними пошукових систем, зроблено велику кількість посилань.

У процесах будь-якої фізичної природи може мати місце явище насичення. Графіки таких процесів отримали назву S-подібних кривих. Їх типове зображення показано на рис. 2. Якщо ці криві можуть бути отримані в результаті розв'язань диференціальних рівнянь, то їх називають логістичними кривими.

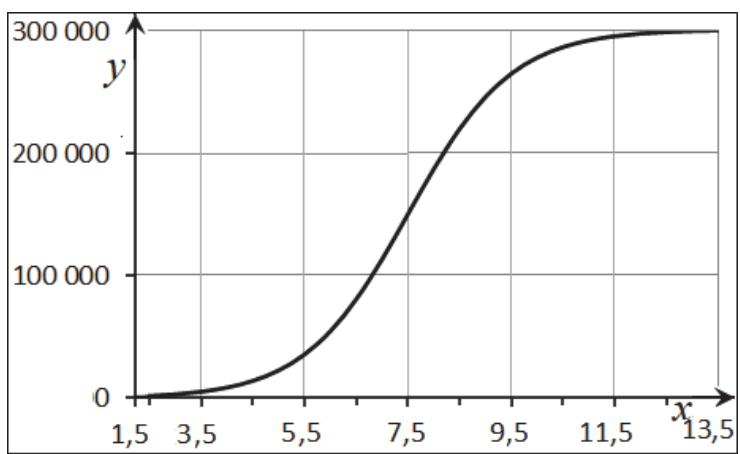

Рис. 2. Типовий вид логістичної кривої

Порівняння зображень на рис. 1 і рис. 2 дозволяє зробити припущення про те, що графік петлі 
гістерезису може бути отриманий 3 графіка Sподібної кривої, використовуючи геометричні перетворення, такі як розтягування, стиснення, паралельне перенесення і поворот координатних осей. Техніка цих перетворень стосовно графіків викладена в багатьох роботах, наприклад в роботах [24; 29].

Розглянемо функцію $y=\operatorname{th}(x)$. Ïї вигляд наведений на рис. 3.

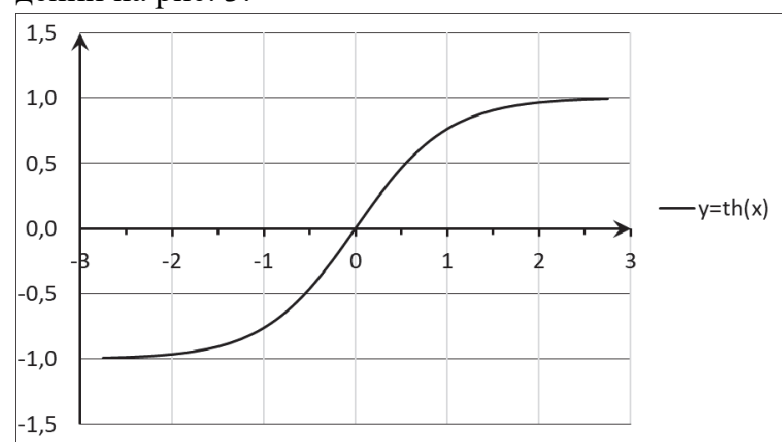

Рис. 3. Графік функції $t h(x)$

Перетворюючи цей графік по формулі

$$
y=1+\operatorname{th}(x)
$$

отримаємо графік вигляду:

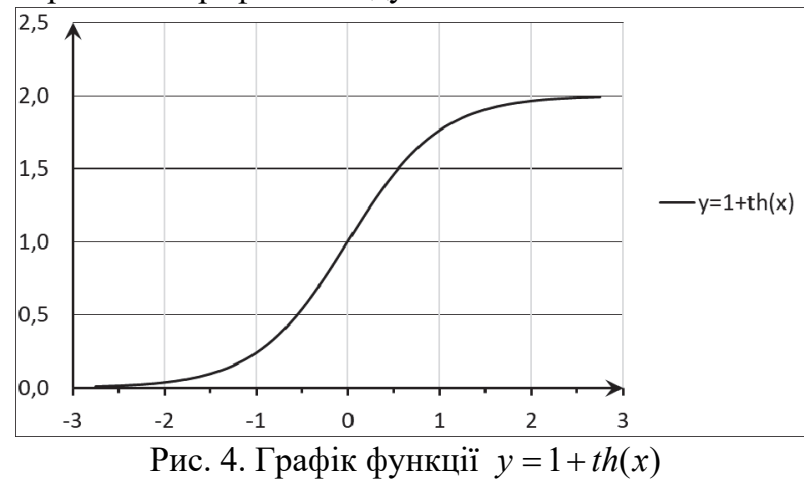

Порівнюючи зображення, приведені на рис. 2 і рис. 4, можна відзначити збіг зовнішнього вигляду графіка логістичної функції і графіка функції $y=1+\operatorname{th}(x)$.

Розглянемо функцію. $y=2+\operatorname{th}(x)$. Ї̈ї вигляд наведений на рис. 5 .

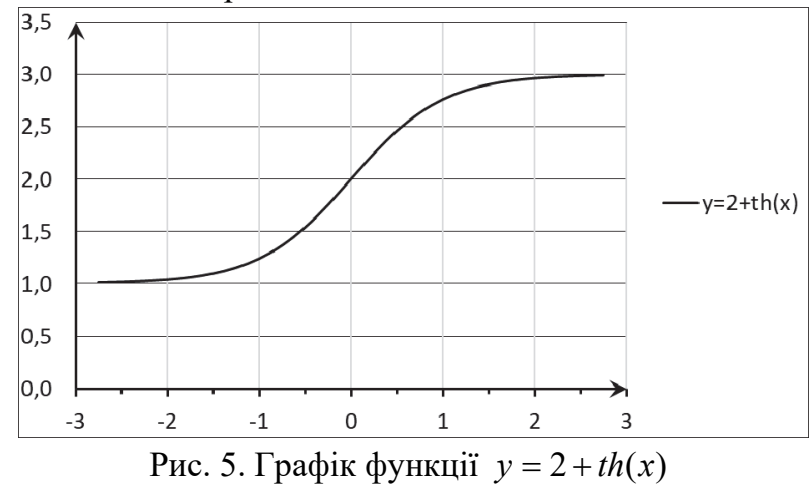

Графік цієї функції співпадає з графіком функції Гомперца, приведеної в роботі [30]. На рис. 6 показано спосіб отримання графіка петлі гістерезису у вигляді комбінації функцій гіперболічного тангенса різних аргументів.

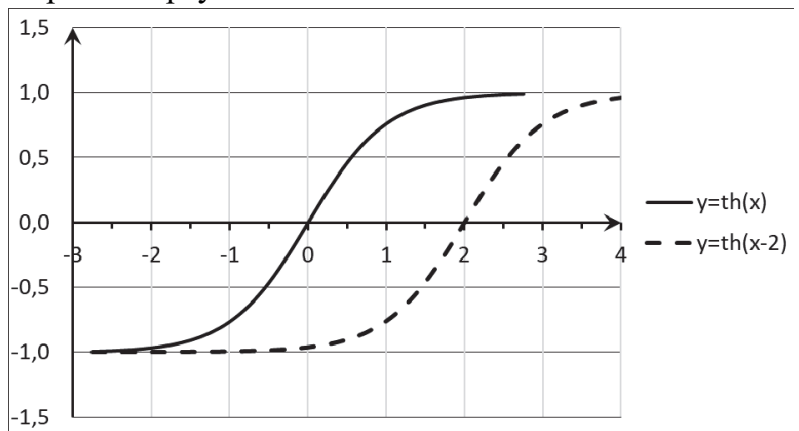

Рис. 6. Отримання графіку петлі гістерезису у вигляді комбінації функції $y=\operatorname{th}(x)$

і функції $y=\operatorname{th}(x-2)$

Слід зазначити, що S-подібні криві знайшли застосування при вивченні різноманітних завдань. Застосування S-подібних кривих при побудові нейронних мереж описано в роботі [25]. Застосування S-подібних кривих при розв'язанні задач оптимізації навчального процесу, пов'язаного з бойовою підготовкою військ, описано в роботі [26].

Важливою методичною особливістю цієї роботи слід зазначити використання функції розподілу Вейбулла для побудови S-подібної кривої. У загальному випадку цей результат можна узагальнити i використовувати функції розподілу при побудові Sподібних кривих різного вигляду.

У роботі [27] показано застосування одного 3 варіантів логістичної функції - функції Ферхюльста як співмножника у функції бажаності Харрінгтона при розв'язанні задач, пов'язаних із забезпеченням безпеки систем газопостачання. У роботі [28] на прикладі аналізу даних про розвиток епідемічного захворювання показано, що в деяких випадках лінійні і експоненціальні моделі зростання можуть бути перетворені в логістичні без втрати інформації про властивості об'єкту дослідження.

Аналіз літератури. Прийнято вважати, що диференціальне рівняння, розв'язання якого давало логістичну криву, отримано в 1831 р. і опубліковане в роботі [31]. Ї̈і продовженням була робота [32]. Аналіз рівняння, отриманого в роботі [31], в сучасній термінології виконано в роботі [33]. Рівняння, яке отримано в роботі [31], має вигляд:

$$
\frac{d x}{d t}=r x\left(1-\frac{x}{K}\right) .
$$

Його розв'язок (логістична крива Ферхюльста) має вигляд:

$$
x(t)=\frac{x_{0} K e^{r \cdot t}}{K-x_{0}+x_{0} e^{r \cdot t}} .
$$

Оскільки 


$$
\lim _{t \rightarrow \infty} \frac{x_{0} K e^{r \cdot t}}{K-x_{0}+x_{0} e^{r \cdot t}}=K,
$$

то рівняння (4) називають рівнянням обмеженого зростання. Автори даного повідомлення не розглядають фізичний зміст отриманого розв'язку, оскільки це виходить за рамки роботи.

Диференціальні рівняння, розв'язання яких приводять до отримання S-подібних кривих, їх змістовний сенс і деякі геометричні властивості якнайповніше розглянуті в роботах [34-36]. Основні типи логістичних i S-подібних кривих, які використовують в технологіях data mining i big data, приведено в роботі [37].

У роботах [34-37] детально розглянуто методи ідентифікації логістичних і S-подібних кривих, але ці методи не адаптовані до ідентифікації петлі гісте- резису. Авторам даної роботи не вдалося знайти в доступній для них літературі методи визначення таких властивостей цих кривих, як: дотична в точці $M\left(x_{0}, y_{0}\right)$, кривина кривої в довільній точці $M(x, y)$, радіус кривини в довільній точці $M(x, y)$, еластичність логістичної кривої і взаємна еластичність по параметрах. Останнє особливо важливе при дослідженні процесів, пов'язаних з отриманням матеріалів із заданими властивостями.

\section{Виклад основного матеріалу}

Постановка завдання. Визначення геометричних властивостей і еластичності по аргументу і параметрах логістичних і S-подібних кривих.

Основні розрахункові співвідношення наведено в роботах [29-30] і табл. 1.

Таблиця 1

Основні геометричні характеристики і еластичність для логістичних і S-подібних кривих

\begin{tabular}{|c|c|c|}
\hline $\begin{array}{c}\text { №№ } \\
\text { П/П }\end{array}$ & Найменування характеристики & Співвідношення \\
\hline 1 & Дотична в точці $\left(x_{0}, y_{0}\right)$ & $y-y_{0}=y_{0}^{\prime}\left(x-x_{0}^{\prime}\right)$ \\
\hline 2 & $\begin{array}{c}\text { Кривина кривої в довільній точці } \\
\qquad M(x, y)\end{array}$ & $K=\frac{\left|y^{\prime \prime}(x)\right|}{\left(1+\left(y^{\prime}\right)^{2}\right)^{3 / 2}}$ \\
\hline 3 & Координати $\xi, \eta$ центру $C$ кривини & $\xi=x-\frac{y^{\prime}\left(1+\left(y^{\prime}\right)^{2}\right)}{y^{\prime \prime}} ; \eta=y+\frac{\left(1+\left(y^{\prime}\right)^{2}\right)}{y^{\prime \prime}} ; y^{\prime \prime} \neq 0$. \\
\hline 4 & $\begin{array}{c}\text { Еластичність функції } \\
y=u(x)\end{array}$ & $E_{x}(y)=\frac{d y}{d x} \cdot \frac{x}{y}$ \\
\hline 5 & $\begin{array}{c}\text { Гранична норма заміщення } \\
\qquad \gamma\left[f\left(x ; \theta_{1}, \theta_{2}\right)\right]\end{array}$ & $\gamma\left[f\left(x ; \theta_{1}, \theta_{2}\right)\right]=\frac{\partial y / \partial \theta_{1}}{\partial y / \theta_{2}}$ \\
\hline
\end{tabular}

Рівняння кривих, геометричні характеристики яких розглянуто в даній роботі, наведено в табл. 2.

Таблиця 2

Рівняння логістичних і S-подібної кривої

\begin{tabular}{|c|c|c|}
\hline Вид кривої & Тип кривої & Рівняння кривої \\
\hline Логістичні криві & Двохпараметрична & $y=\frac{\exp (a+b x)}{1+\exp (a+b x)}$ \\
\cline { 1 - 3 } & Трьохпараметрична & $y=\frac{a}{1+b \exp (-c x)}$ \\
\cline { 2 - 3 } & Чотирьохпараметрична & $y=a+\frac{b-a}{1+b \exp \left(\frac{c-x}{d}\right)}$ \\
\cline { 2 - 3 } & Крива Гомперца & $y=a \exp [-b \exp (c x)]$ \\
\hline S-подібна крива & Крива Вейбулла & $y=1-b\left[\exp \left(-c x^{d}\right)\right]$ \\
\hline
\end{tabular}

Співвідношення, необхідні для розрахунку геометричних характеристик кривих, які визначені в табл. 2, наведені в табл. $3 \ldots 7$. 
Основні геометричні характеристики і еластичність для двохпараметричної логістичної кривої

\begin{tabular}{|c|c|}
\hline $\begin{array}{c}\text { Найменування } \\
\text { характеристики }\end{array}$ & Співвідношення \\
\hline $\begin{array}{l}\text { Рівняння дотичної } \\
\text { в точці } M\left(x_{0}, y_{0}\right)\end{array}$ & $y-y_{0}=\frac{a \exp \left(a x_{0}+b\right)}{\left(a \exp \left(a x_{0}+1\right)\right)^{2}}\left(x-x_{0}\right)$ \\
\hline Допоміжні змінні & $\begin{array}{c}z=a x+b \\
U 1=\frac{\exp (4 z)+4 \exp (3 z)+\exp (2 z) \cdot\left(a^{2}+b\right)+4 \exp (z)+1}{a(1-\exp (z)) \cdot(\exp (z)+1)^{3}} \\
W 1=\frac{\exp (-z) \cdot U 1}{a^{2}\left(1-z^{3}\right)}\end{array}$ \\
\hline $\begin{array}{c}\text { Кривина кривої в довільній } \\
\text { точці } M(x, y)\end{array}$ & $k=\frac{a^{2} \exp (z) \cdot(\exp (z)+1)^{3}|\exp (z)-1|}{\left[\exp (4 z)+4 \exp (3 z)+\exp (2 z) \cdot\left(a^{2}+b\right)+4 \exp (z)+1\right]^{3 / 2}}$ \\
\hline $\begin{array}{l}\text { Координати } \xi, \eta \\
\text { центру кривини C }\end{array}$ & $\xi=x-U 1 ; \eta=y+W 1$ \\
\hline Еластичність кривої & $E_{x}(y)=\frac{b x}{1+\exp (z)}$ \\
\hline Гранична норма заміщення & $\gamma(x ; a, b)=\frac{1}{x}$ \\
\hline
\end{tabular}

Таблиця 4

Основні геометричні характеристики і еластичність для трьохпараметричної логістичної кривої

\begin{tabular}{|c|c|}
\hline $\begin{array}{l}\text { Найменування } \\
\text { характеристики }\end{array}$ & Співвідношення \\
\hline $\begin{array}{l}\text { Рівняння дотичної } \\
\text { в точці } M\left(x_{0}, y_{0}\right)\end{array}$ & $y-y_{0}=\frac{a b c \exp \left(x_{0}\right)}{(\exp (c x)+b)^{2}}\left(x-x_{0}\right)$ \\
\hline Допоміжні змінні & $\begin{array}{c}t=\exp (c) \\
U 2=\exp (4 t)+4 b \exp (3 t)+b^{2} \exp (2 t) \cdot\left(a^{2} c^{2}+6\right)+4 b^{3} \exp (t)+b^{4}\end{array}$ \\
\hline $\begin{array}{c}\text { Кривина кривої в довільній } \\
\text { точці } M(x, y)\end{array}$ & $k=\frac{c^{2} \exp (c x) \cdot(\exp (c x)-b) \cdot \operatorname{sign}(\exp (c x)-b) \cdot|\exp (c x)+b|^{3} \cdot|a b|}{(U 2)^{3 / 2}}$ \\
\hline $\begin{array}{l}\text { Координати } \xi, \eta \\
\text { центру кривини С }\end{array}$ & $\xi=x-\frac{(U 2)}{c\left(b-t^{x}\right) \cdot\left(t^{x}+b\right)^{3}} ; \eta=y+\frac{-t^{x}(U 2)}{a b c^{2}\left(b^{2}-t^{2 x}\right)}$ \\
\hline Еластичність кривої & $E_{x}(y)=\frac{b c x}{\exp (c x)+b}$ \\
\hline Гранична норма заміщення & $\gamma(x ; a, b)=-\frac{t^{x}+b}{a} ; \gamma(x ; a, c)=\frac{t^{x}+b}{a b x} ; \gamma(x ; b, c)=-\frac{1}{b x}$ \\
\hline
\end{tabular}


Таблиця 5

Основні геометричні характеристики і еластичність для чотирьохпараметричної логістичної кривої

\begin{tabular}{|c|c|}
\hline $\begin{array}{c}\text { Найменування } \\
\text { характеристики }\end{array}$ & Співвідношення \\
\hline Допоміжні змінні & $\begin{array}{l}G=\exp (x / d)+b \exp (c / d) ; A=\frac{b \exp \left(\frac{x+c}{d}\right) \cdot(b-a)}{d \cdot G^{2}} \\
B=\frac{b \exp \left(\frac{x+c}{d}\right) \cdot(a-b) \cdot[\exp (x / d)-b \exp (c / d)]}{d^{2} \cdot[G+b \exp (x / d)]^{3}}\end{array}$ \\
\hline $\begin{array}{l}\text { Рівняння дотичної } \\
\text { в точці } M\left(x_{0}, y_{0}\right)\end{array}$ & $y-y_{0}=\frac{b \exp \left(\frac{x_{0}+c}{d}\right) \cdot(b-a)}{d \cdot G^{2}} \cdot\left(x-x_{0}\right)$ \\
\hline $\begin{array}{c}\text { Кривина кривої в довільній } \\
\text { точці } M(x, y)\end{array}$ & $k=\frac{|B|}{[1+A]^{3 / 2}}$ \\
\hline $\begin{array}{l}\text { Координати } \xi, \eta \\
\text { центру кривини C }\end{array}$ & $\xi=x-\frac{A\left(1+A^{2}\right)}{B} ; \eta=y+\frac{1+A^{2}}{B}$ \\
\hline Еластичність кривої & $E_{x}(y)=\frac{x \cdot \exp \left(\frac{x+c}{d}\right) \cdot(b-a)}{d \cdot G[\exp (x / d)+a \exp (c / d)]}$ \\
\hline Гранична норма заміщення & $\begin{array}{c}\gamma(x ; a, b)=\frac{b G \exp \left(\frac{c-x}{d}\right)}{\exp (x / d)+a \exp (c / d)} \\
\gamma(x ; a, c)=\frac{d \cdot G \cdot \exp \left(\frac{c-x}{d}\right)}{a-b} ; \gamma(x ; a, d)=\frac{d^{2} \cdot G \exp (-x / d)}{(a-b) \cdot(x-c)} \\
\gamma(x ; b, c)=\frac{d \cdot G \exp (-c / d)[\exp (x / d)+a \exp (c / d)]}{b(a-b)} ; \\
\lambda(x ; b, d)=\frac{d^{2} \exp (-c / d) \cdot[\exp (x / d)+a \exp (c / d)]}{b(a-b)(x-c)} \\
\gamma(x ; c, d)=\frac{d}{x-c}\end{array}$ \\
\hline
\end{tabular}

Основні геометричні характеристики і еластичність для логістичної кривої Гомперца

\begin{tabular}{|c|c|}
\hline $\begin{array}{c}\text { Найменування } \\
\text { характеристики }\end{array}$ & Співвідношення \\
\hline $\begin{array}{c}\text { Рівняння дотичної } \\
\text { в точці } M\left(x_{0}, y_{0}\right)\end{array}$ & $y-y_{0}=\left[-a b c \exp \left(c x_{0}-b e^{c x_{0}}\right)\right] \cdot\left(x-x_{0}\right)$ \\
\hline $\begin{array}{c}\text { Кривина кривої } \\
\text { в довільній точці } M(x, y)\end{array}$ & $k=\frac{c^{2} \exp [2 b \exp (c x)+c x] \cdot\left|a b^{2} \exp (c x)-a b\right|}{\left[\exp (2 b \exp (c x))+(a b c \exp (c x))^{2}\right]^{3 / 2}}$ \\
\hline Допоміжні змінні & $\begin{array}{c}W=\exp (2 b \exp (c x)) \cdot(b c x \exp (c x)-c x+1)+(a b c \exp (c x))^{2} \\
\text { Координати } \xi, \eta \\
\text { центру кривини С }\end{array}$ \\
\hline Еластичність кривої & $\xi=\frac{\exp (-2 b \exp (c x)) \cdot(U 3)}{c x} ; \eta=\frac{\exp (-b \exp (c x)) \cdot(W 3)}{a b c^{2}(b \cdot \exp (c x)-1)}$ \\
\hline Гранична норма заміщення & $E_{x}(y)=-b c x \exp (c x)$ \\
\hline
\end{tabular}


Основні геометричні характеристики і еластичність для S-подібної кривої Вейбулла

\begin{tabular}{|c|c|}
\hline Найменування характеристики & Співвідношення \\
\hline \multirow[t]{2}{*}{ Допоміжні змінні } & $\Pi 1=b c \cdot d \cdot \exp \left(-c x^{d}\right)$ \\
\hline & $\Pi 2=\left(c \cdot d \cdot x^{d}\right)^{2}+3 c \cdot d \cdot x^{d}(1-d)+(d-1)(d-2)$ \\
\hline $\begin{array}{l}\text { Рівняння дотичної } \\
\text { в точці } M\left(x_{0}, y_{0}\right)\end{array}$ & $\begin{array}{l}y-y_{0}=x_{0}^{d-1}\left(\Pi 1 \mid x=x_{0}\right)\left(x-x_{0}\right) \\
y-y_{0}=b c d \exp \left(-c x_{0}^{d}\right) \cdot\left(x-x_{0}\right)\end{array}$ \\
\hline $\begin{array}{c}\text { Кривина кривої } \\
\text { в довільній точці } M(x, y)\end{array}$ & $k=\frac{\left|x^{d-3} \cdot \Pi 1 \cdot \Pi 2\right|}{\left[1+\left(x^{d-1} \cdot \Pi 1\right)\right]^{3 / 2}}$ \\
\hline $\begin{array}{l}\text { Координати } \xi, \eta \\
\text { центру кривини C }\end{array}$ & $\xi=x-\frac{\left(x^{d-1} \cdot \Pi 1\right)}{x^{d-3} \cdot \Pi 1 \cdot \Pi 2} \cdot\left[1+\left(x^{d-1} \cdot \Pi 1\right)^{2}\right] ; \eta=y+\frac{1+\left(x^{d-1} \cdot \Pi 1\right)^{2}}{x^{d-3} \cdot \Pi 1 \cdot \Pi 2}$ \\
\hline Еластичність кривої & $E_{x}(y)=\frac{b c \cdot d x^{d}}{\exp \left(c x^{d}\right)-b}$ \\
\hline Гранична норма заміщення & $\gamma(x ; b, c)=-\frac{x^{-d}}{b} ; \gamma(x ; b, d)=-\frac{x^{-d}}{b c \ln x} ; \gamma(x ; c, d)=-\frac{1}{c \ln x}$ \\
\hline
\end{tabular}

Таким чином, в роботі запропоновано спосіб отримання петлі гістерезису перетворенням логістичних і S-подібних кривих. Отримано рівняння, які дають можливість не тільки надавати опис петлі гістерезису, але і класифікувати їх залежно від таких геометричних характеристик, як рівняння дотичної, кривина кривої і координати центру кривини. Рівняння еластичності надають можливість вивчити вплив відносної зміни властивостей зовнішнього середовища на відносну зміну значення функції, яку вивчають. Гранична норма заміщення надає можливість оцінити вплив внутрішніх властивостей по відношенню до явища, що вивчається, на значення функції, що вивчається. Це може бути корисним при синтезі матеріалів із заданими властивостями.

Історико-бібліографічне доповнення. При знайомстві з роботою [16] було зазначено, що їі зовнішній вигляд істотно відрізняється від вимог до оформлення статей, прийнятих сьогодні. Результати зробленого дослідження цього питання наведено далі. В списку літератури, що відноситься до цього розділу роботи, прийнято, що бібліографічний опис робіт, опублікованих після 1.01.1918 р., виконано відповідно до сучасних вимог, бібліографічний опис робіт, опублікованих до 1.01.1918 р., виконано за правилами того часу з використанням орфографії оригіналу. Для прикладу взято статті Н.Е. Жуковського [38], А.С. Попова [39], А. Эйнштейна [40], В.О. Костіцина [16,43], О.Ю. Шмідта [41], збірки [42], Я.І. Грдіни [44]. Включення цих робіт обумовлене тим, що компетентність авторів і високі вимоги до оформлення робіт у виданнях, що їх публікували, сумнівів не викликає. На підтвердження слід зауважити, що на титульному аркуші журналів вказували не тільки прізвище головного редактора, але і прізвище того, хто “тримав коректуру”, тобто співробітника редакції, що виконував обов'язки літературного редактора і коректора [39; 45 С. 290]. Зміну стилю наукових публікацій в часі показано в табл. 8.

Зміна в часі стилю наукових публікацій

\begin{tabular}{|c|c|c|c|c|}
\hline \multirow{2}{*}{$\begin{array}{c}\text { Рік публікації, } \\
\text { публікація }\end{array}$} & Країна & $\begin{array}{c}\text { Наявність анотації, } \\
\text { мова анотації }\end{array}$ & \multicolumn{2}{|c|}{ Оформлення списку літератури } \\
\cline { 3 - 4 } & Росія & - & - & $\begin{array}{c}\text { Перелік наприкінці } \\
\text { основного тексту }\end{array}$ \\
\hline $1887,[38]$ & Росія & - & + & - \\
\hline $1896,[39]$ & Німеччина & - & + & - \\
\hline $1905,[40]$ & Росія & Французька & + & - \\
\hline $1916,[44]$ & &
\end{tabular}


Закінчення табл. 8

\begin{tabular}{|c|c|c|c|c|}
\hline $1928,[16],[41]$ & СРСР & Французька або німецька & + & - \\
\hline $1935,[43]$ & Франція & - & - & + \\
\hline $1945,[42]$ & СРСР & англійська & - & + \\
\hline Сучасні вимоги & Україна & $\begin{array}{c}\text { англійська, } \\
\text { мова статті - українська, } \\
\end{array}$ & англійська & \\
\hline
\end{tabular}

3 цієї таблиці видно, як геополітичні потрясіння XX століття змінювали не тільки політичну карту світу, але навіть і вимоги до оформлення статей наукових видань.

У списку робіт, наведених в табл. 8, присутні роботи двох чоловіків, долі яких об'єднує одна обставина, - обидва вони жили в Україні в 1917-1918 буренних роках.

Один 3 них - Я.І. Грдіна, вже був добре відомий як автор багатьох оригінальних наукових ідей, другий - В.О. Костіцин, який зробив серйозний вплив не тільки на розвиток наукових досліджень, але і на хід подій, відомих під назвою Українські визвольні змагання 1917-1921 pp.

Я.І. Грдіна (1871-1931) - 31902 р. професор Катеринославського Вищого Гірничого Училища. 3 цих пір і до кінця своїх днів діяльність Я.І. Грдіни тісно пов'язана $з$ вишами Катеринослава, Дніпропетровська (Дніпра). Його біографію детально описано в роботі [46]. Я.І. Грдіна був одним 3 перших науковців, які проводили дослідження в новітній тоді області фізики - теорії відносності [44]. Аналіз його досліджень з сучасних позицій зроблено в роботі [47]. Я. І. Грдіна справедливо може бути названий також батьком однієї з гілок кібернетики - біоніки [48]. Я.І. Грдіну, принаймні це витікає з робіт його біографів, минули потрясіння і трагедії тих років: ОСВАГ Денікіна, репресії ВЧК-ОГПУ, арешти НКВС, Промпартія, СВУ та інші негаразди тих, зовсім “невегетаріанських", часів. Життя він прожив зовні благополучне, швидше за все схоже 3 життям Миколи Степановича, героя чеховської "Скучної історії” [49]. Але ж це тільки на перший погляд. 3 1926 р. він перебував в оперативній розробці ДПУНКВС як один з ватажків “фашистської організації професури ДГІ”, розгромленої у 1937 р. [55, С. 72 77]. Ще раз підкреслимо дати його життя: 18711931.

Життя В.О. Костіцина, продовжуючи літературні аналогії, можна порівняти 3 життям героїв О. Дюма. При підготовці даного повідомлення автори, бажаючи ознайомитися 3 роботами В.О. Костіцина, зіткнулися 3 дивовижними обставинами. 3 1928 р. по 1984 р. в Радянському Союзі не було видано жодної роботи В.О. Костіцина. Робота [50] була перекладена з французького видання 1935 р. [16]. Редактором роботи [50] був академік Н.Н. Моїсеєв. У написаній ним передмові біографія В.О. Костіци- на викладена 3 такими натяками і лакунами, що скласти реальне уявлення про життя цієї людини було практично неможливо. На даний час основні відомості про біографію В.О. Костіцина в російськомовній літературі можна прочитати в передмові В.Л. Геніса до книги [51]. В україномовній літературі участь В.О. Костіцина в революційних подіях 1917 року описана в роботі [52]. Про активність участі В.О. Костіцина в цих подіях можна судити з даних, приведених в іменному покажчику роботи [52]. Всього в цьому покажчику названо 518 прізвищ. Від 21 до 30 разів згадано тільки 5 прізвищ. В.О. Костіцин згаданий 21 раз.

Володимир Олександрович Костіцин (18831963) у 1902-1906 роках навчався на фізикоматематичному відділенні Московського університету. Під час навчання вступив до РСДРП, брав активну участь у революційних подіях 1905-1907 років, отримав важке поранення на барикадах. У 1907 році заарештований, провів у одиночній камері 17 місяців. Після звільнення емігрував до Франції, де продовжив заняття математикою у Сорбонні. Був знайомий з багатьма емігрантами - більшовиками. Після початку Першої Світової війни повернувся до Росії. 3 лютого 1917 року брав активну участь у революційних подіях у Петрограді, був начальником міліції Лісного району Петрограду. У серпні 1917 року призначений помічником комісара ПівденноЗахідного фронту, керував групою, яка заарештувала генерала А.І. Денікіна під час корнілівського виступу. Згодом донька Денікіна - Маргарет Саммервіль згадувала слова свого батька про те, що чесному Костіцину була не властива кровожерність.

25 жовтня 1917 року у Вінниці стався більшовицький переворот. Для протидії йому штаб Південно-Західного фронту наказав В.О. Костіцину сформувати загін, до складу якого увійшли три сотні козаків, батальйон юнкерів, відділення броньового дивізіону, кулеметно-автомобільне відділення та артилерійська батарея. Вранці в неділю 29 жовтня Костіцин видав наказ: “Частинам застави м. Вінниці. Оголошую, що бунт, який вчинила жменька безвідповідальних осіб проти Тимчасового уряду й революційної демократії, що залив братерською кров'ю вулиці Петрограду, Москви, Києва, Вінниці та інших міст Російської Республіки, сьогодні спільними зусиллями вірного Батьківщині Революційного війська й військових організацій, придушено. 
Спокій і лад у країні, що був порушений божевільною спробою викликати анархію й колотнечу, відновлюється. Зважаючи на те, що цей лад відновлено кров'ю й жертвами справжніх синів Батьківщини, я, військовий комісар Тимчасового уряду, оголошую, що буду нещадно душити всіляку нову спробу бунту, скерованого проти Тимчасового уряду й Республіки, й усіх, хто винен у бунті, підбурюванні чи будь-якому іншому опорові владі, неухильно віддаватиметься під військово-революційній суд”. Заколот було подавлено. В.О. Костіцин спочатку наказав розстріляти кожного десятого з полонених, але потім наказ відмінив. 7 листопада 1917 року до Вінниці надійшло повідомлення: “Верховною владою на Україні є Центральна рада і iї орган - Генеральній Секретаріат".

Весною 1918 року В.О. Костіцин повернувся до життя науковця. У своїй математичній роботі Костіцин вивчав різні види інтегральних рівнянь. У 1924 р. він зробив доповідь “Деякі застосування інтегральних рівнянь до задач магнітного гістерезису” на Міжнародному конгресі математиків в Торонто. В кінці 1928 року він поїхав у наукове відрядження до Франції і дізнався про підготовку арешту. Після чого прийняв рішення не повертатися до СРСР. В еміграції його науковий інтерес набув нового напрямку: він зайнявся розв'язанням математичних задач біології і еволюційної теорії. Костіцин опублікував монографії: "Симбіоз, паразитизм і еволюція" (1934), “Еволюція атмосфери, біосфери і клімату" (1935), "Математична біологія" (1937; англійський переклад - 1939). Він зустрічався 3 Вернадським, який знаходився в 1932 р. у Франції. Бесіди з ним стимулювали появу в тому ж році статті “Про одне застосування диференціальних рівнянь в геологіі”. Після окупації Парижу німецькими військами в 1940 р. Костіцин був ув'язнений у табір, але через деякий час звільнений. У повоєнні роки Костіцин продовжив свої дослідження в різних областях природознавства.

I Я.І. Грдіна, і В.О. Костіцин прожили свої життя в повній відповідності із словами, приведеними в роботі [53]: “Людина повинна бути причет- ною до діянь і пристрастей своєї епохи, інакше можуть визнати, що вона ніколи не жила".

\section{Висновки}

1. В роботі розглянуто методи побудови математичних моделей явища гістерезису, які придатні для опису цього явища в об'єктах довільної природи.

2. В результаті аналізу літератури встановлено, що явище гістерезису спостерігається не тільки у фізиці, але й у багатьох галузях знань, таких, як моделювання антитерористичних операцій, опис роботи різних механізмів, гідрогеологія, економіка, планування навчального процесу.

3. Показано, що в цих випадках найбільш вдалим методом апроксимації петлі гістерезису буде використання S-подібних (логістичних) кривих. Наведено приклад побудови S-подібної (логістичної) кривої, використовуючи перетворення графіка функції гіперболічного тангенсу.

4. В роботі досліджено властивості двохпараметричних, трьохпараметричних та чотирьохпараметричних логістичних кривих, S-подібних кривих Гомперца і Вейбулла.

5. В роботі наведено вирази для визначення таких властивостей кривих, як: дотична в точці $M\left(x_{0}, y_{0}\right)$, кривина кривої в довільній точці $M(x, y)$, радіус кривини в довільній точці $M(x, y)$, координати $\xi, \eta$ центру $C$ кривини, еластичність функції по аргументу і взаємна еластичність по параметрах. Останнє особливо важливе при дослідженні процесів, пов'язаних з отриманням матеріалів із заданими властивостями.

6. Рівняння еластичності надають можливість вивчити вплив відносної зміни властивостей зовнішнього середовища на відносну зміну значення функції, яку вивчають. Гранична норма заміщення надає можливість оцінити вплив внутрішніх, по відношенню до явища, що вивчається, властивостей, на значення функції, що вивчається. Це може бути корисним при синтезі матеріалів із заданими властивостями.

\section{Список літератури}

1. Физика: словарь-справочник / Е.С. Платунов, В.А. Самолетов, С.Е. Буравой, С.С. Прошкин, под редакцией Н.М. Кожевникова. - Санкт-Петербург: Издание Политехнического университета, 2014. - 798 с.

2. Райхлин Раддай. Гражданская война, террор и бандитизм (Систематизация социологии и социальная динамика) [Электронный ресурс]. - Режим доступа: https://modernlib.net/books/rayhlin_radday/grazhdanskaya_voyna_terror i banditizm sistematizaciya_sociologii_i socialnaya_dinamika/read_1/-10.01.2021 г. - Загл. с экрана.

3. Яскевич А.В. Математические модели гистерезиса, описывающие деформации механизмов для стыковки космических аппаратов / А.В. Яскевич // Труды Московского авиационного института. - 2015 - Вып. № 83. -. С. 106-116.

4. Расчет сканирующих ветвей с использованием данных о главных ветвях гистерезиса водоудерживающей способности на примере песчаных почв / В.В. Терлеев, А.Г. Топаж, К.Г. Моисеев, Р.С. Гиневский, В.А. Лазарев // Метеорология и гидрогеология. - 2015. - № 6. - С. 34-42.

5. Динамическая модель рыночного равновесия в условиях гистерезисного поведения экономических агентов / М.Е. Семенов, М.Ю. Мишин, Е.Г. Кабулова, Е.А. Абополова // Современная экономика: проблемы и решения. - 2015. Том 7, апрель. - С. 146-155. 
6. Бессонов Л.А. Теоретические основы электротехники / Л.А. Бессонов. - Москва: Высшая школа, 1996. - 638 с.

7. Hauser H. Hysteresis modeling and measurement for woodimensional particle assembles / H. Hauser, P.L. Fulmek,

R. Grossinger // J. of Magnetism and Magnetic Materials. Physica B. - 2000. - Vol. 275. - P. 24-39.

8. Ионов И.П. Магнитные элементы дискретного действия. / И.П. Ионов. - Москва: Высшая школа, 1968. - 284 с.

9. Hermann W. Dommel. Digital computer solution of electromagnetic transients in single- and multiphase networks / Hermann W. Dommel // IEEE Transactions on Power Apparatus and Systems. - 1969. - Vol. 88. - No. 4. - P. 388-399.

10. Deane J.H.B. Modeling the dynamics of nonlinear inductor circuits / J.H.B. Deane // IEEE Transactions on Magnetics. - 1994. - Vol. 30. - Issue 5. - P. 1-13.

11. Андреев М.В. Математическая модель магнитного гистерезиса, базирующаяся на теории Прейзаха / М.В. Андреев, М.В. Спица, А.В. Киевец // Вестник Иркутского государственного технического университета. - 2018. - Т. 22. № 8. - С. 104-113.

12. Красносельский М.А. Системы с гистерезисом / М.А. Красносельский, А.В. Покровский. - Москва: Наука, 1983. $-271 \mathrm{c}$.

13. Леонов Г.А. Устойчивость систем с гистерезисом / Г.А. Леонов, М.М. Шумафов, В.А. Тешев. - Майкоп: Издательство Адыгейского Университета, 2012. - 178 с.

14. Гурченков А.А. Математика в экономике (Гистерезис) [Электронный ресурс] / А.А. Гурченков, А.И. Фесечко. Вычислительный центр им. А.А. Дородницына. - Режим доступа: https://cyberleninka.ru/article/n/matematika-v-ekonomikegisterezis?gclid=EAIaIQobChMI5ZjZoMeT7gIVgu-yCh3xoQM1EAMYASAAEgK9EfD_BwE / - 11.01.2021 г. Загл. с экрана.

15. Смирнов В.И. Курс высшей математики. Т. 2 / В.И. Смирнов. - Москва: ГТТИ, 1957. - 628 с.

16. Костицын В.А. Опыт математической теории гистерезиса / В.А. Костицын // Математический сборник.- 1924. Том 32. - №1. - С. 192-202.

17. Сарычев В.А. Математическая модель гистерезиса, основанная на магнитомеханической аналогии / В.А. Сарычев, В.И. Пеньков, М.Ю. Овчинников // Математическое моделирование. - 1989. - Том 1. - № 4. - С. 122-133.

18. Король Е.Г. Анализ методов моделирования петли гистерезиса ферромагнитных материалов / Е.Г. Король // Електротехніка і Електромеханіка. - 2007. - № 6. - С. 44-47.

19. Lapshin R.V. Analytical model for the approximation of hysteresis loop and its application to the scanning tunneling microscope / R.V. Lapshin // Review of Scientific Instruments. - 1995. - Vol. 66. - No. 9. - P. 4718-4730.

20. Попов Е.П. Приближенные методы исследования нелинейных автоматических систем / Е.П. Попов, И.П. Пальтов. - Москва: Физматгиз, 1960. - 792 с.

21. Ильин В.М. Метод аналитической аппроксимации петель гистерезиса / В.М. Ильин // Доклады Белорусского государственного университета информатики и радиоэлектроники. - 2006. - Апрель-июнь № 2 (14). - С. 57-63.

22. Бокринская А.А. Аналитическое представление петли гистерезиса / А.А. Бокринская, Б.А. Медведев // Известия вузов. Радиоэлектроника. - 1972. - Том 15. - № 1. - С. 73-78.

23. Зирка С.Е. Алгоритмы моделирования гистерезиса в задачах магнетодинамики / С.Е. Зирка, Ю.И. Мороз // Технічна електродинаміка. - 2002. - № 5. - С. 7-13.

24. Егерев В.К. Методика построения графиков функций / В.К. Егерев, Б.А. Радунский, Д.А. Тальский. - Москва: Высшая школа, 1970. - 152 с.

25. Элементарное введение в технологию нейронных сетей с примерами программ / Р. Тадеусевич, Б. Боровик, Т. Гончаж, Б. Леппер. - Москва: Горячая линия - Телеком, 2011. - 408 с.

26. Годзь С.В. Математична модель визначення загального обсягу навчальних годин комплексної програми бойової підготовки військового формування типу з'єднання (частина) будь-якого ступеня готовності / С.В. Годзь, В.М. Можаровський // Системи обробки інформації. - 2020. - № 2(161). - С. 96-110. https://doi.org/10.30748/soi.2020.161.06.

27. Музиченко М.В. Використання логістичної функції Ферхюльста як функції бажаності для нормування показників безпеки постачання природного газу / М. В. Музиченко // Економіка і суспільство. - 2017. - Вип. № 9. - С. 83-88.

28. Шевченко В.Л. Грубі моделі розвитку в медицині / В.Л. Шевченко, А.В. Шевченко // Медична інформатика та інженерія. - 2009. - № 4. - С. 52-55.

29. Корн Г. Справочник по математике для научных работников и инженеров / Г. Корн и Т. Корн. - Москва: Наука, 1968. $-720 \mathrm{c}$.

30. Лук'яненко І.Г. Економетрика / І.Г. Лук'яненко, Л.І. Краснікова. - К.: Знання, КОО, 1998. - 494 с.

31. Verhulst P.F. Notice sur la loi que la population suit dans son accroissement / P.F. Verhulst // Correspondance Mathematique et Physique public A. 10. - 1838. - P. 113-121.

32. Pearl R. On the rate of growth of the population of the United States since 1790 and its mathematical representation/ R. Pearl, L.J. Reed // Proceedings of the National Academy of Science USA. - 1920. - 6. - P. 275-288.

33. Ризниченко Г.Ю. Лекции по математическим моделям в биологии. Часть 1. / Г.Ю. Ризниченко. - Ижевск: НИЦ Регулярная и хаотическая динамика, 2002. - 232 стр.

34. Семёнычев В.К. Параметрическая идентификация рядов динамики: структуры, модели, эволюция: монография / В.К. Семёнычев, Е.В. Семёнычев. - Самара: Издательство СамНЦ РАН, 2011. - 364 с.

35. Семёнычев В.К. Анализ и предложения моделей экономической динамики с кумулятивным логистическим трендом: монография / В.К. Семёнычев, В.Н. Кожухова. -Самара: Изд-во СамНЦ РАН, 2013. - 310 с.

36. Семенычев В.К. Предложения эконометрического инструментария моделирования и прогнозирования эволюционных процессов: монография / В.К. Семенычев, А.А. Коробецкая, В.Н. Кожухова. - Самара: САГМУ, 2015. - 384 с.

37. Мыльников Л.А. Статистические методы интеллектуального анализа данных / Л.А. Мыльников. - Санкт - Петербург: БХВ-Петербург, 2021. - 240 с.

38. Н.Е. Жуковскій, О движеніи вязкой жидкости, заключенной между двумя вращающимися эксцентрическими цилиндрическими поверхностями, Сообщ. и протоколы засћданій Матем. общ. при Император. Харьков. унив. 1887 года, 1887, выпуск 1, 31-46.

39. Приборъ для обнаруженія и регистрированія электрическихъ колебаній А. С. Попова. ЖУРНАЛЬ РУССКАГО ФИЗИКО - ХИМИЧЕСКАГО ОБЩЕСТВА при Императорскомъ С. - Петербургскомъ Университетћ. Томъ ХХVІІІ.ВЫПУСКЪ 1. 1896 г. ФИЗИЧЕСКАЯ. ОТДћЛ, С. 1-14. 
40. Albert Einstein - Zur Elektrodynamik bewegter Körper. Annalen der Physik, IV. Folge 17. Seite 891-921. Juni, 1905.

41. Шмидт О.Ю. Группы, все подгруппы которых специальные / О.Ю. Шмидт // Математический сборник. - 1924. - том 31, № 3-4. - С. 366-372.

42. А.С. Попов. Сборник документов : к 50-летию изобретения радио / А.С. Попов [Составили Г.И. Головин и Р.И. Карлина; под редакцией члена-корреспондента Академии наук СССР М.А. Шателена. - [Ленинград]: Ленинградское газетно-журнальное и книжное издательство, 1945. -255 с.

43. Evolution de l'atmosphère: circulation organique, époques glaciaires / par V.A. Kostitzin. - Hermann. 1935. -45 p.

44. Я. ГрдиНа ФИЗИЧЕСКІЙ ИЛИ ОГРАНИЧННЫЙ ПРИНЦИПЪ ОТНОСИТЕЛЬНОСТИ. ЖУРНАЛЬ РУССКАГО ФИЗИКО - ХИМИЧЕСКАГО ОБЩЕСТВА при Императорскомъ С. - Петербургскомъ Университетћ. Томъ ХLVIII.ВЫПУСКЪ 1.1916 г. ЧАСТЬ ФИЗИЧЕСКАЯ. С. 35-68.

45. Ожегов С.И. Словарь русского языка / С.И. Ожегов. - Москва: Издательство “Советская энциклопедия”, 1968. $-900 \mathrm{c}$

46. Путятя Т.В. Ярослав Иванович Грдина / Т.В. Путята, Б.Н. Фридман. - Москва: Наука, 1970. - 112 с.

47. Колтачихіна О.Ю. Сприйняття теорії відносності в Україні в першій третині XX ст. / О.Ю. Колтачихіна // Наука та наукознавство. - 2006. - № 4. Додаток. - С. 84-88.

48. Манзей С.Ф. Бионика для науки и техники / С.Ф. Манзей // Вестник зоологии. - 1967. - № 1. - С. 17-23.

49. Чехов А.П. Скучная история / А.П. Чехов. // Собрание сочинений: В 8 томах. - Т. 4. - С. 276-334. - Москва: Издательство “Правда", 1970.

50. Костицын В. А. Эволюция атмосферы, биосферы и климата. Перевод с французского. Под редакцией и с предисловием Н.Н. Моисеева / В. А. Костицын. - Москва: НАУКА, 1984. - 96 с.

51. Костицын В. Моё утраченное счастье. Воспоминания, дневники. Вступительная статья В.Л. Гениса / В.А. Костицын. - Москва: ООО “Новое литературное обозрение”, 2017. - 271 с.

52. Логінов О.В. Вінниця у 1917 році: Революція у провінційному місті / О.В. Логінов, Л.І. Семенко. - Вид. 2-ге, виправ. - Вінниця: ДП Державна картографічна фабрика, 2011. - 272 с.

53. Уилсон М. Встреча на далёком меридиане / М. Уилсон. - Москва: Мир, 1964. - 429 с.

54. Левченко Н.А. Применение ЭЦВМ для расчета схем на ферритах и сегнетоэлектриках / Н.А.Левченко. - Киев: Наукова Думка, 1969. - 272 с.

55. Швидко Н.А. Нариси 3 історії Національного гірничого університету (1899-2015) / Н.А. Швидко. - Дніпро: ДніпроНГУ, 2015. - 170 с.

\section{References}

1. Platunov, E.S., Samoletov, V.A., Buravoj, S.E. and Proshkin, S.S. (2014), “Fizika: slovar'-spravochnik” [Physics: dictionary-reference], Polytechnic University publication, St. Petersburg, 798 p.

2. Raikhlin, Radday (2016), "Grazhdanskaja vojna, terror i banditizm (Sistematizacija sociologii i social'naja dinamika)" [Civil war, terror and banditry (Systematization of sociology and social dynamics)], Available at: https://modernlib.net/books/rayhlin_radday/grazhdanskaya_voyna_terror_i_banditizm_sistematizaciya_sociologii_i_socialnaya_ dinamika/read_1/ (accessed 25.02.2021).

3. Yaskevich, A.V. (2015), "Matematicheskiye modeli gisterezisa, opisyvayushchiye deformatsii mekhanizmov dlya stykovki kosmicheskikh apparatov" [Mathematical models of hysteresis, describing the deformation of mechanisms for docking spacecraft], Proceedings of the Moscow Aviation Institute, No. 83, pp. 106-116.

4. Terleev, V.V., Topazh, A.G., Moiseev, K.G., Ginevskiy, R.S. and Lazarev, V.A. (2015), "Raschet skaniruyushchikh vetvey s ispol'zovaniyem dannykh o glavnykh vetvyakh gisterezisa vodouderzhivayushchey sposobnosti na primere peschanykh pochv" [Calculation of scanning branches using data on the main branches of the hysteresis of water-holding capacity on the example of sandy soils], Meteorology and Hydrogeology, No. 6, pp. 34-42.

5. Semenov, M.E., Mishin, M.Yu., Kabulova, E.G. and Abopolova, E.F. (2015), "Dinamicheskaya model' rynochnogo ravnovesiya $\mathrm{v}$ usloviyakh gisterezisnogo povedeniya ekonomicheskikh agentov" [Dynamic model of market equilibrium in conditions of hysteresis behavior of economic agents], Modern Economics: Problems and Solutions, Vol. 7, pp. 146-155.

6. Bessonov, L.A. (1996), "Teoreticheskiye osnovy elektrotekhniki" [Theoretical foundations of electrical engineering], Vysshya shkola, Moscow, 638 p.

7. Hauser, H., Fulmek, P.L. and Grossinger, R. (2000), Hysteresis modeling and measurement for woodimensional particle assembles, J. of Magnetism and Magnetic Materials, Physica B, Vol. 275, pp. 24-39.

8. Ionov, I.P. (1968), "Magnitnyye elementy diskretnogo deystviya" [Discrete magnetic elements], Vysshya shkola, Moscow, $284 \mathrm{p}$.

9. Dommel, Hermann W. (1969), Digital computer solution of electromagnetic transients in single- and multiphase networks, IEEE Transactions on Power Apparatus and Systems, Vol. 88, No. 4, pp. 388-399.

10. Deane, J.H.B. (1994), Modeling the dynamics of nonlinear inductor circuits, IEEE Transactions on Magnetics, Vol. 30, Issue 5, pp. 1-13.

11. Andreev, M.V., Spica, M.V. and Kievec, A.V. (2018), "Matematicheskaja model' magnitnogo gisterezisa, bazirujushhajasja na teorii Prejzaha" [Mathematical model of magnetic hysteresis, based on the theory of Preisakh], Vestnik Irkutskogo gosudarstvennogo tehnicheskogo universiteta, Vol. 22, No. 8, pp. 104-113.

12. Krasnoselsky, M.A. and Pokrovsky, A.V. (1983), "Sistemy s gisterezisom" [Systems with hysteresis], Nauka, Moscow, $271 \mathrm{p}$.

13. Leonov, G.A., Shumafov, M.M., and Teshev, V.A. (2012), "Ustoychivost' sistem s gisterezisom" [Stability of systems with hysteresis], Izdatel'stvo Adygeyskogo Universiteta, Maykop, 178 p.

14. Gurchenkov, A.A. and Fesechko, A.I. "Matematika v ekonomike (Gisterezis)" [Mathematics in Economics (Hysteresis)], Computing Center named after A.A. Dorodnitsyn. Available at: https://cyberleninka.ru/article/n/matematika-v-ekonomikegisterezis?gclid=EAIaIQobChMI5ZjZoMeT7gIVgu-yCh3xoQM1EAMYASAAEgK9EfD_BwE (accessed 25.02.21). 
15. Smirnov, V.I. (1957), "Kurs vysshey matematiki v 6 t. T.2" [Course of higher mathematics in 6 volumes. Vol.2], GTTI, Moscow, 628 p.

16. Kostitsyn, V.A. (1924), "Opyt matematicheskoy teorii gisterezisa" [Experience of the mathematical theory of hysteresis], Matematicheskiy sbornik, Vol. 32, No.1, pp. 192-202.

17. Sarychev, V.A., Penkov, V.I. and Ovchinnikov, M,Yu. (1989), "Matematicheskaya model' gisterezisa, osnovannaya na magnitomekhanicheskoy analogii" [Mathematical model of hysteresis based on magnetomechanical analogy], Mathematical modeling, Vol. 1, No. 4, pp. 122-133.

18. Korol, Ye.G. (2007), "Analiz metodov modelirovaniya petli gisterezisa ferromagnitnykh materialov" [Analysis of modeling methods for the hysteresis loop of ferromagnetic materials], Elektrotekhnika i Elektromekhanika, No. 6, pp. 44-47.

19. Lapshin, R.V. (1995), Analytical model for the approximation of hysteresis loop and its application to the scanning tunneling microscope, Review of Scientific Instruments, Vol, 66, No. 9, pp. 4718-4730.

20. Popov, E.P. and Paltov, I.P. (1960), "Priblizhennyye metody issledovaniya nelineynykh avtomaticheskikh system" [Approximate methods of research of nonlinear automatic systems], Fizmatgiz, Moscow, $792 \mathrm{p}$.

21. Ilyin, V.M. (2006), "Metod analiticheskoj approksimacii petel' gisterezisa" [Method of analytical approximation of hysteresis loops], Reports of the Belarusian State University of Informatics and Radioelectronics, No. 2(14), pp. 57-63.

22. Bokrinskaya, A.A. and Medvedev, B.A. (1972), "Analiticheskoye predstavleniye petli gisterezisa" [Analytical representation of the hysteresis loop], Izvestiya vuzov. Radioelektronika, Vol. 15, No. 1, pp. 73-78.

23. Zirka, S.E. and Moroz, Yu.I. (2002), "Algoritmy modelirovaniya gisterezisa v zadachakh magnetodinamiki” [Algorithms for modeling hysteresis in problems of magnetodynamics], Technical Electrodynamics, No. 5, pp. 7-13.

24. Yegerev, V.K., Radunskiy, B.A. and Talskiy, D.A. (1970), "Metodika postroyeniya grafikov funktsiy" [The method of constructing graphs of functions], Higher school, Moscow, $152 \mathrm{p}$.

25. Tadeusevich, R., Borovik, B., Gonchazh, T. and Lepper, B. (2011), "Elementarnoye vvedeniye v tekhnologiyu neyronnykh setey s primerami programm" [An elementary introduction to the technology of neural networks with examples of programs], Goryachaya liniya - Telekom, Moscow, 408 p.

26. Hodz, S.V. and Mozharovsky, V.M. (2020), "Matematychna model vyznachennia zahalnoho obsiahu navchalnykh hodyn kompleksnoi prohramy boiovoi pidhotovky viiskovoho formuvannia typu ziednannia (chastyna) bud-yakoho stupenia hotovnosti" [Mathematical model for determining the total amount of training hours of a comprehensive program of combat training of the military formation of the type of connection (part) of any degree of readiness], Information Processing Systems, No. 2(161), pp. 96-110. https://doi.org/10.30748/soi.2020.161.06.

27. Muzychenko, M.V. (2017), "Vykorystannya lohistychnoyi funktsiyi Ferkhyul'sta yak funktsiyi bazhanosti dlya normuvannya pokaznykiv bezpeky postachannya pryrodnoho hazu" [The use of the logistics function of Verhulst as a function of desirability for the rationing of safety indicators for natural gas supply], Economy and Society, Issue 9, pp. 83-88.

28. Shevchenko, V.L. and Shevchenko, A.V. (2009), "Hrubi modeli rozvytku v medytsyni" [Rough models of development in medicine], Medical Informatics and Engineering, No. 4, pp. 52-55.

29. Korn, G. and Korn, T. (1968), "Spravochnik po matematike dlya nauchnykh rabotnikov $i$ inzhenerov" [Handbook of mathematics for scientists and engineers], Nauka, Moscow, $720 \mathrm{p}$.

30. Lukyanenko, I.G. and Krasnikova, L.I. (1998), “Ekonometryka” [Econometrics], Znannya, Kyiv, 494 p.

31. Verhulst, P.F. (1838), Notice sur la loi que la population suit dans son accroissement, Correspondance Mathematique et Physique par A. 10. pp. 113-121.

32. Pearl, R. and Reed, L.J. (1920), On the rate of growth of the population of the United States since 1790 and its mathematical representation, Proceedings of the National Academy of Science USA, No. 6, pp. 275-288.

33. Riznichenko, G.Yu. (2002), "Lektsii po matematicheskim modelyam v biologii. Chast' 1" [Lectures on Mathematical Models in Biology. Part1], Regulyarnaya i khaoticheskaya dinamika, Izhevsk, 232 p,

34. Semyonichev, V.K. and Semyonichev, E.V. (2011), "Parametricheskaya identifikatsiya ryadov dinamiki: struktury, modeli, evolyutsiya: monografiya" [Parametric identification of series of dynamics: structures, models, evolution: monograph], Publishing house SamSC RAS, Samara, 364 ,

35. Semyonichev, V.K. and Kozhukhova, V.N. (2013), “Analiz i predlozheniya modeley ekonomicheskoy dinamiki s kumulyativnym logisticheskim trendom: monografiya" [Analysis and proposals of models of economic dynamics with a cumulative logistic trend: monograph], Publishing house SamSCRAS, Samara, $310 \mathrm{p}$.

36. Semenychev, V.K. Korobetskaya, A.A. and Kozhukhova, V.N. (2015), "Predlozheniya ekonometricheskogo instrumentariya modelirovaniya i prognozirovaniya evolyutsionnykh protsessov: monografiya" [Proposals of econometric tools for modeling and forecasting evolutionary processes: monograph], SAGMU, Samara, 384 p.

37. Mylnikov, L.A. (2021), "Statisticheskiye metody intellektual'nogo analiza dannykh" [Statistical methods of data mining], BHV-Petersburg, St. Petersburg, 240 p.

38. Zhukovskij, N.E. (1887), "O dvizhenii vjazkoj zhidkosti, zakljuchennoj mezhdu dvumja vrashhaushhimisja jekscentricheskimi cilindricheskimi poverhnostjami" [On the motion of a viscous fluid between two rotations. eccentric cylindrical surfaces], Soobshhenija i protokoly zasedanij Matematicheskogo obshhestva pri Imperatorskom Har'kovskom universitete 1887 goda, vypusk 1,1887, pp. 31-46, ().

39. Popov, A.S. (1896), "Pribor dlya obnaruzheniya i registrirovaniya elektricheskikh kolebaniy A.S. Popova" [Device for detecting and registering electrical oscillations A.S. Popov], ZHURNAL RUSSKOGO FIZIKO - KHIMICHESKOGO OBSHCHESTVA pri Imperatorskom S. - Peterburgskom Universitete. Tom XXVIII.VYPUSK 1. FIZICHESKAYA. OTDEL C, (JOURNAL OF THE RUSSIAN PHYSICO-CHEMICAL SOCIETY at the Imperial St. Petersburg University. Volume XXVIII. ISSUE 1. 1896 PHYSICAL. DEPARTMENT C), pp. 1-14.

40. Einstein, A. (1905), "Zur Elektrodynamik bewegter Körper" [To the electrodynamics of moving media], Annalen der Physik, IV. Folge 17. Seite 891-921. Juni, 1905.

41. Shmidt, O.Yu. (1924), "Gruppy, vse podgruppy kotorykh spetsial'nyye" [Groups, all subgroups of which are special], Matematicheskiy sbornik, Vol. 31, No. 3-4, pp. 366-372.

42. Golovin, G.I. and Karlina, R.I. (1945), “A.S. Popov. Sbornik dokumentov: k 50-letiju izobretenija radio; pod redakciej chlena-korrespondenta Akademii nauk SSSR M. A. Shatelena” [A.S. Popov. Collection of documents: to the 50th anniversary of 
the invention of radio, edited by M.A. Shatelin, Corresponding Member of the USSR Academy of Sciences], Leningradskoe gazetno-zhurnal'noe i knizhnoe izdatel'stvo, Leningrad, $255 \mathrm{p}$.

43. Kostitzin, V.A. (1935), Evolution de l'atmosphère: circulation organique, époques glaciaires par V.A.Kostitzin, Hermann, $45 \mathrm{p}$.

44. Grdina, Y.A. (1916), "FIZICHESKIY ILI OGRANICHENNYY PRINTSIP OTNOSITEL'NOSTI” [PHYSICAL OR LIMITED PRINCIPLE OF RELATIVITY], ZHURNAL RUSSKOGO FIZIKO - KHIMICHESKOGO OBSHCHESTVA pri Imperatorskom S. - Peterburgskom Universitete, Vol. XLVIII, Issue 1, pp. 35-68.

45. Ozhegov, S.I. (1968), "Slovar' russkogo yazyka" [Dictionary of the Russian language], Publishing House "Soviet Encyclopedia", Moscow, 900 p.

46. Putyata, T.V, and Fridman, B.N. (1970), "Yaroslav Ivanovich Grdina" [Yaroslav Ivanovich Grdina], Nauka, Moscow, $112 \mathrm{p}$.

47. Koltachykhina, O.Yu. (2006), "Spryiniattia teorii vidnosnosti v Ukraini v pershii tretyni XX st." [Perception of the theory of relativity in Ukraine in the first third of the twentieth century], Nauka ta naukoznavstvo, No. 4, Addition, pp. 84-88.

48. Manzey, S.F. (1967), "Bionika dlya nauki i tekhniki" [Bionics for Science and Technology], Vestnik zoology, No. 1, pp. 17-23.

49. Chekhov, A.P. (1970), "Skuchnaya istoriya" [Boring story], Collected works: In 8 volumes. Vol. 4, Publishing House "Pravda", Moscow, pp. 276-334.

50. Kostitsyn, V.A. (1984), "Evolyutsiya atmosfery, biosfery i klimata. Perevod s frantsuzskogo. Pod redaktsiyey is predisloviyem N.N. Moiseyeva" [Evolution of the atmosphere, biosphere and climate. Translated from French. Edited and prefaced by N.N. Moiseev], NAUKA, Moscow, 96 p.

51. Kostitsyn, V. (2017), "Moyo utrachennoye schast'ye. Vospominaniya, dnevniki. Vstupitel'naya stat'ya V.L. Genisa" [My Lost Happiness. Memories, diaries. Introductory article by V.L. Genis], "Novoye literaturnoye obozreniye", Moscow, 271 p.

52. Lohinov, O.V. and Semenko, L.I. (2011), "Vinnytsya u 1917 rotsi: Revolyutsiya u provintsiynomu misti" [Vinnytsia in 1917: Revolution in the provincial city, View. 2nd, corrected], Derzhavna kartohrafichna fabryka, Vinnytsya, $272 \mathrm{p}$.

53. Wilson, M. (1964), "Vstrecha na dalokom meridiane" [Meeting on the distant meridian], Mir, Moscow, $429 \mathrm{p}$.

54. Levchenko, N.A., (1969), "Primeneniye ETSVM dlya rascheta skhem na ferritakh i segnetoelektrikakh" [Application of electronic digital computers for calculating circuits based on ferrites and ferroelectrics], Naukova Dumka, Kyiv, $272 \mathrm{p}$.

55. Shvydko, H.K. (2015), "Narysy z istorii Natsionalnoho hirnychoho universytetu (1899-2015)" [Essays on the history of the National Mining University (1899-2015)], DniproNGU, Dnipro, 170 p.

Надійшла до редколегї 09.04.2021

Схвалена до друку 12.05.2021

\section{Відомості про авторів:}

\section{Гадецька Світлана Вікторівна}

кандидат фізико-математичних наук доцент

доцент Харківського національного

автомобільно-дорожнього університету,

Харків, Україна

https://orcid.org/0000-0002-9125-2363

\section{Дубницький Валерій Юрійович}

кандидат технічних наук

старший науковий співробітник

старший науковий співробітник

навчально-наукового інституту “Каразінський

банківський інститут” Харківського національного

університету ім. В.Н. Каразіна,

Харків, Україна

https://orcid.org/0000-0003-1924-4104

\section{Кушнерук Юрій Іонович}

кандидат технічних наук доцент

доцент Харківського національного університету

Повітряних Сил ім. І. Кожедуба,

Харків, Україна

https://orcid.org/0000-0001-5844-7137

\section{Філатова Любов Дмитрівна}

кандидат фізико-математичних наук доцент доцент навчально-наукового інституту “Каразінський банківський інститут” Харківського національного університету ім. В.Н. Каразіна,

Харків, Україна

https://orcid.org/0000-0002-6605-3442

\section{Information about the authors:}

\section{Svitlana Gadetska}

$\mathrm{PhD}$ in Physics and Mathematics Associate Professor

Senior Lecturer of Kharkiv National

Automobile and Highway University,

Kharkiv, Ukraine

https://orcid.org/0000-0002-9125-2363

\section{Valeriy Dubnitskiy}

Candidate of Technical Sciences

Senior Research

Senior Research Associate

of "Karazin Banking Institute"

of V.N. Karazin Kharkiv

National University,

Kharkiv, Ukraine

https://orcid.org/0000-0003-1924-4104

\section{Youriy Kushneruk}

Candidate of Technical Sciences Associate Professor

Senior Lecturer of Ivan Kozhedub

Kharkiv National Air Force University,

Kharkiv, Ukraine

https://orcid.org/0000-0001-5844-7137

\section{Lyubov Filatova}

$\mathrm{PhD}$ in Physics and Mathematics Associate Professor Senior Lecturer of "Karazin Banking Institute"

of V.N. Karazin Kharkiv

National University,

Kharkiv, Ukraine

https://orcid.org/0000-0002-6605-3442 
Ходирсв Олександр Іванович

старший викладач навчально-наукового інституту

“Каразінський банківський інститут” Харківського національного університету ім. В.Н. Каразіна,

Харків, Україна

https://orcid.org/0000-0001-9871-9440
Alexander Khodyrev

Senior Instructor of "Karazin Banking Institute"

of V.N. Karazin Kharkiv

National University,

Kharkiv, Ukraine

https://orcid.org/0000-0001-9871-9440

\title{
ГЕОМЕТРИЧЕСКИЕ ХАРАКТЕРИСТИКИ S-ОБРАЗНЫХ (ЛОГИСТИЧЕСКИХ) КРИВЫХ, ИСПОЛЬЗУЕМЫХ ПРИ МОДЕЛИРОВАНИИ ЯВЛЕНИЯ ГИСТЕРЕЗИСА
}

\author{
С.В. Гадецкая, В.Ю. Дубницкий, Ю.И. Кушнерук, Л.Д. Филатова, А И. Ходырев
}

В работе рассмотрены методы построения математических моделей явления гистерезиса, пригодные для описания этого явления в объектах произвольной природы. В результате анализа литературы установлено, что явление гистерезиса наблюдается не только в физике, но и во многих отраслях знаний, таких как моделирование антитеррористических операций, описание работы различных механизмов, гидрогеология, экономика. Показано, что в этих случаях наиболее удачным методом аппроксимачии петли гистерезиса будет использование S-образных (логистических) кривых. Приведен пример построения S-образной (логистической) кривой с использованием преобразования графика функиии гиперболического тангенса. В работе исследованы свойства двухпараметрических, трёхпараметрических и четырёхпараметрических логистических кривых, S-образных кривых Гомпериа и Вейбулла. В работе определены такие свойства этих кривых, как: касательная в точке $M\left(x_{0}, y_{0}\right)$, кривизна кривой в произвольной точке $M(x, y)$, радиус кривизны в произвольной точке $M(x, y)$, координаты $\xi, \eta$ иентра С кривизны, эластичность функции по аргументу и взаимная эластичность по параметрам. Последнее особенно важно при исследовании процессов, связанных с получением материалов с заданными свойствами. Полученные соотночения позволяют не только описывать кривые гистерезиса, но и классифицировать их в зависимости от их геометрических характеристик. Соотнотения эластичности позволяют изучить влияние относительного изменения свойств внешней, по отношению к изучаемому явлению среды, на относительное изменение значения изучаемой функиии. Предельная норма замещения даёт возможность оценить влияние внутренних, по отношению к изучаемому явлению свойств, на значение изучаемой функции. Это может быть использовано при синтезе материалов с заданными свойствами. В историко-библиографическом дополнении к данной работе показано, как в течение XIX-XXI cm. редакции научно-технических журналов Европы меняли требования к оформлению статей.

Ключевые слова: гистерезис, модель гистерезиса, S-образные (логистические) кривые, двухпараметрические, трёхпараметрические и четырёхпараметрические логистические кривые, кривые Гомпериа и Вейбулла.

\section{GEOMETRIC CHARACTERISTICS OF S-FORM (LOGISTIC) CURVES APPLIED IN HYSTERESIS PHENOMENON MODELING}

S. Gadetska, V. Dubnitskiy, Y. Kushneruk, L. Filatova, A. Khodyrev

The work discusses methods of hysteresis phenomenon mathematical model construction eligible for description of this phenomenon in random nature objects. Analysis of literature showed that hysteresis phenomenon takes place not only in physics, but in many other fields of knowledge, such as modeling of anti-terror operations, working description of various mechanisms, hydrogeology, economics. In those cases the most successful hysteresis loop approximation method was shown to be application of S-form (logistic) curves. An example was given how an S-form (logistic) curve was constructed by transformation of hyperbolic tangent function plot. He work studied the properties of two-parameter, three-parameter, four-parameter logistic curves, Sform, Gomperz and Weibull's curves. Such properties of those curves were defined as: tangent at point $M\left(x_{0}, y_{0}\right)$, curve's curvature at random point $M(x, y)$, radius of curvature at random point $p M(x, y)$, coordinates $\xi, \eta$ of curvature center $C$, function elasticity by argument and mutual elasticity by parameters. The latter is especially important in study of processes connected with manufacture of materials with set-up properties. The obtained equations enable not only description of hysteresis curves, but also their classification depending on their geometric characteristics. Elasticity equations permit to study the effect of relative amendment in properties of medium external as regards the phenomenon under study upon the value of studied function. Marginal rate of substitution enables estimation of the effect relative change in properties of medium internal as regards the phenomenon under study upon the value of studied function. This may find application in synthesis of materials with set-up properties. Historical bibliography supplement to this work demonstrates evolution in editorial requirements of European scientific magazines to presentation of articles within the period XIX-XXI centuries.

Keywords: hysteresis, hysteresis model, S-form (logistic) curves, two-parameter, three-parameter, four-parameter logistic curves, Gomperz and Weibull's curves. 